\title{
Hormone-induced changes in nuclear receptor stoichiometry in HL60 cells correlate with induction of monocyte or neutrophil differentiation
}

\author{
P G McTernan, M C Sheppard and G R Williams ${ }^{1}$ \\ Department of Medicine, University of Birmingham, Edgbaston, Birmingham B15 2TT, UK and ${ }^{1}$ Molecular Endocrinology Group, Department of Medicine, \\ Imperial College School of Medicine, London W12 0NN, UK \\ (Requests for offprints should be addressed to G R Williams, Molecular Endocrinology Group, Department of Medicine, Clinical Sciences Centre, \\ Imperial College School of Medicine, The Hammersmith Campus, Hammersmith Hospital, Du Cane Road, London W12 0NN, UK)
}

\begin{abstract}
HL60 cells differentiate to monocytes or neutrophils in response to $1 \alpha, 25(\mathrm{OH})_{2}$-vitamin $\mathrm{D}_{3}\left(\mathrm{D}_{3}\right)$ and retinoids respectively. $\mathrm{D}_{3}$ and retinoid actions converge since their receptors (VDR, RAR) heterodimerise with a common partner, RXR, which also interacts with thyroid hormone $\left(T_{3}\right)$ receptors $\left(T_{3} R\right)$. HL60 cells were treated with combinations of $\mathrm{D}_{3}$ and retinoids to induce differentiation and to investigate whether increased VDR or RAR expression correlated with monocyte or neutrophil differentiation and whether altered receptor concentrations affected DNA-binding specificity. As assessed by Western blotting, VDR and RXR expression was unchanged in monocytes relative to controls but levels of $R A R$ and $T_{3} R$ were reduced. In contrast, only VDR expression was
\end{abstract}

reduced in neutrophils. $\mathrm{T}_{3}$ did not promote differentiation or influence its induction by $\mathrm{D}_{3}$ or retinoids and did not affect expression of any receptor. Gel mobility-shift analysis revealed that nuclear extracts from undifferentiated cells, monocytes and neutrophils interacted differently with VDRE-, RARE- and RXRE-binding sites. Monocyte nuclear protein/DNA complexes contain readily detectable VDR and RXR whereas neutrophil complexes contain RAR and RXR. Thus hormone-induced changes in receptor stoichiometry favour either VDR/RXR or RAR/RXR heterodimerisation and correlate with hormone-induced differentiation of HL60 cells to monocytes or neutrophils respectively.

Journal of Endocrinology (1998) 156, 135-148

\section{Introduction}

Human promyeloctic leukaemia cells (HL60) differentiate to monocytes or granulocytes (neutrophils) in response to specific stimuli. In particular, treatment with $1 \alpha, 25-$ dihydroxyvitamin $\mathrm{D}_{3}\left(\mathrm{D}_{3}\right)$ promotes monocyte differentiation whilst retinoids induce neutrophil differentiation (Collins et al. 1977, Breitman et al. 1980). We have also shown that retinoids synergise with $\mathrm{D}_{3}$ to promote monocyte differentiation (Brown et al. 1994). Furthermore, variation of $\mathrm{D}_{3}$ and retinoid concentration ratios over an extensive range promotes differentiation along either the monocyte or neutrophil pathway (not both) or induces cellular apoptosis (Bunce et al. 1995). The synthetic $\mathrm{D}_{3}$ analogues, EB1089 and KH1060, also effectively induce monocyte differentiation of HL60 cells but their relative potencies are inversely correlated with their ability to synergise with retinoids (Brown et al. 1994).

$\mathrm{D}_{3}$ and retinoid actions are mediated by related nuclear receptors that are members of the steroid/thyroid hormone receptor superfamily (Evans 1988). The receptors act as ligand-inducible transcription factors which bind to hormone response element DNA sequences in target gene promoters and regulate their transcriptional activation or repression (Katzenellenbogen et al. 1996). There is a single receptor for $\mathrm{D}_{3}$ (VDR) (Ozono et al. 1991), three separate genes encoding receptors for all-trans-retinoic acid (RAR $\alpha, \beta, \gamma$ ) (Mattei et al. 1991) and three encoding receptors for 9-cis-retinoic acid (RXR $\alpha, \beta, \gamma)$ (Mangelsdorf et al. 1992, Mangelsdorf 1994). VDR and RAR proteins preferentially bind to related response elements (VDRE and RARE) as heterodimers with their common partner, RXR, which can also form functional heterodimers with tri-iodo-thyronine $\left(T_{3}\right)$ receptor $\left(T_{3} R\right)$ (Kliewer et al. 1992, Leid et al. 1992, Glass 1994). In addition, VDR, RAR and $\mathrm{T}_{3} \mathrm{R}$ proteins can heterodimerise with each other (Rosen et al. 1993, Schrader et al. 1994) or bind to DNA as homodimers (Yen et al. 1992, Zhang et al. 1992, Cheskis \& Freedman 1994). Precise roles for each possible receptor dimer combination have yet to be determined and it is not clear which receptor complexes occur in vivo, although the high-affinity RXRcontaining heterodimers are considered to be predominant and the most physiologically important. A large number of 
in vitro biochemical and transfection studies have shown that the control of specific hormone responses by VDR, $\mathrm{RAR}, \mathrm{RXR}$ and $\mathrm{T}_{3} \mathrm{R}$ is complex and hierarchical (Glass 1994, Williams 1994, Katzenellenbogen et al. 1996). The many receptor variants and their heterodimerisation potential leads to an array of possible receptor dimers, and the likelihood of complex interactions between their signalling pathways, in cells that co-express multiple receptors. Such interactions vary according to the target gene and cell type studied and may be modified by changes in receptor stoichiometry and the relative concentrations of activating hormones as well as by other recently characterised adaptor proteins (Williams 1994, Katzenellenbogen et al. 1996). It is not yet known which, if any, of these mechanisms are associated with the induction of monocyte versus neutrophil differentiation in HL60 cells by $\mathrm{D}_{3}$ and retinoids.

Using previously defined hormone treatment combinations to induce monocyte or neutrophil differentiation of HL60 cells (Brown et al. 1994, Bunce et al. 1995), we have tested the possibility that preferred activation of a particular signalling pathway may be associated with increased expression of its cognate nuclear receptor by addressing the following hypotheses. First, that VDR-mediated stimulation of HL60 monocyte differentiation correlates with induction of VDR expression and; secondly, that retinoidinduced HL60 neutrophil differentiation correlates with increased RAR or RXR expression. We further investigated whether changes in relative concentrations of expressed nuclear receptors in hormone-induced HL60 cells were associated with altered DNA-binding specificity of nuclear extracts to hormone response elements.

\section{Materials and Methods}

\section{HL60 cell culture and reagents}

Cultures of HL60 cells were maintained in serum-free RPMI 1640 medium (Gibco, Paisley, UK) containing penicillin $(100$ units $/ \mathrm{ml})$ and streptomycin $(100 \mu \mathrm{g} / \mathrm{ml})$, supplemented with insulin, transferrin, $\mathrm{Se}_{2} \mathrm{O}_{3}$, linoleic acid and BSA (ITS ${ }^{+}$; Advanced Protein Products, Smethwick, UK) as described (Brown et al. 1994). HL60 cells were maintained in exponential growth from a seeding density of $2.5 \times 10^{5}$ cells $/ \mathrm{ml}$ to a maximum density of $1.25 \times 10^{6}$ cells $/ \mathrm{ml}$. Stock solutions of $3,5,3^{\prime}{ }^{-}$L-triiodothyronine $\left(\mathrm{T}_{3}\right)$ (Sigma Chemical Co., Poole, Dorset, UK) $\left(10^{-4} \mathrm{M}\right.$ in $\left.0 \cdot 02 \mathrm{M} \mathrm{NaOH}\right), \mathrm{D}_{3}, \mathrm{~EB} 1089((1 S, 3 R)-$ dihydroxy- $(20 R)-\left(5^{\prime}\right.$-ethyl-5'-hydroxyhepta- $\left(1^{\prime} E, 3^{\prime} E\right)$ diene-1'-yl)-9,10-secopregna-(5Z,7E),10(19)-triene) and KH1060 ((1S,3R)-dihydroxy-(20R)-(4'-hydroxy-4' ethyl1'-hexyloxy)-9,10-secopregna-(5Z,7E),10(19)-triene) (Leo Pharmaceutical Products Ltd A/S, Ballerup, Denmark) $\left(4 \times 10^{-3} \mathrm{M}\right.$ in isopropanol), all-trans-retinoic acid (RA) (Sigma) $\left(10^{-2} \mathrm{M}\right.$ in methanol) and 9-cis-retinoic acid (9cisRA) (Hoffman-La Roche, Nutley, NJ, USA) $\left(10^{-4} \mathrm{M}\right.$ in ethanol) were diluted in medium.

\section{Induction of monocyte differentiation}

The synthetic analogues EB1089 and KH1060 are more potent than the parent compound, $\mathrm{D}_{3}$, in suppressing proliferation of the promonocyte cell line U937 (Binderup et al. 1991) and in promoting monocyte differentiation of HL60 cells (Brown et al. 1994). Monocyte differentiation of HL60 cells was induced by addition of either $\mathrm{D}_{3}$ or analogue alone, or in combination with either RA or 9cisRA, to growing cells initially seeded at $2.5 \times 10^{5}$ cells $/ \mathrm{ml}$ and maintained in exponential growth to a maximum density of $1.25 \times 10^{6}$ cells $/ \mathrm{ml}$ over 5 days. In time course experiments, identically seeded and maintained cells were harvested at $0,1,2,3,4$ and 5 days after induction of differentiation $\left(\mathrm{D}_{3}, 50 \mathrm{nM}\right)$ and compared with matched untreated control cells at each time point. The concentrations of $\mathrm{RA}, \mathrm{D}_{3}$ and synthetic analogues used to induce monocyte differentiation were derived in previous studies (Brown et al. 1994, Bunce et al. 1995) and are indicated in the legends to Figs 2, 3 and 4.

\section{Induction of neutrophil differentiation}

Neutrophil differentiation of HL60 cells was induced by addition of RA alone, or in combination with a low concentration of $\mathrm{D}_{3}$ which does not itself promote HL60 differentiation (Bunce et al. 1995), to growing cells initially seeded at $2.5 \times 10^{5}$ cells $/ \mathrm{ml}$ and maintained in exponential growth to a maximum density of $1.2 \times 10^{6}$ cells $/ \mathrm{ml}$ over 5 days. The concentrations of agents used to induce neutrophil differentiation were derived in previous studies (Bunce et al. 1995) and are indicated in the legend to Fig. 4.

\section{Effect of $T_{3}$ on induction of monocyte and neutrophil differentiation}

The effect of $\mathrm{T}_{3}$ on induction of HL60 cell differentiation was examined by inducing monocyte or neutrophil differentiation over 5 days as above, in the absence or presence of $\mathrm{T}_{3}(1 \mathrm{nM}$ or $100 \mathrm{nM})$. The concentrations of agents used in individual experiments are indicated in the legend to Fig. 5. The maximum final concentrations of methanol, ethanol, isopropanol and $\mathrm{NaOH}$ vehicles used in hormone treatments were 1/100 000, 1/1000, 1/40000 and $1 / 1000(\mathrm{v} / \mathrm{v})$ dilutions respectively. Control cultures treated with any vehicle at the upper concentrations showed no evidence of cell differentiation in any of the inductions described above.

\section{Assessment of cell differentiation}

Non-specific differentiation of HL60 cells to either monocytes or granulocytes (neutrophils) was assessed by measurement of the proportion of cells that could phagocytose complement-coated yeast (Toksoz et al. 1982). To determine whether mature HL60 cells had differentiated 
to either neutrophils or monocytes, cytocentrifuged preparations of cells were stained for monocyte-specific esterase using $\alpha$-naphthylacetate ester as substrate (Yam et al. 1971) and with May-Grunwald-Giemsa for assessment of cell morphology as previously described (Brown et al. 1994, Bunce et al. 1995).

\section{Nuclear protein preparation}

Nuclear protein preparations were obtained as previously described for osteosarcoma cells (Williams et al. 1994, 1995). Briefly, HL60 cells were cultured in $175 \mathrm{~cm}^{2}$ flasks and maintained in RPMI 1640 medium for 5-day treatment periods. Cells were washed with PBS, pelleted and resuspended in $4 \mathrm{ml} \mathrm{STM} \mathrm{(sucrose} 0.25 \mathrm{M}$, Tris- $\mathrm{HCl}$ $\left.20 \mathrm{mM}, \mathrm{MgCl}_{2} 1.1 \mathrm{mM}, \mathrm{pH} 7 \cdot 85\right)+0.5 \mathrm{mM}$ phenylmethylsulphonyl fluoride (PMSF; Sigma). Cells were pelleted at $800 \mathrm{~g}, 4^{\circ} \mathrm{C}, 10 \mathrm{~min}$ and resuspended in $3.5 \mathrm{ml}$ STM+PMSF containing 0.5\% Triton X-100 (Sigma) and incubated on ice for $10 \mathrm{~min}$. This step was repeated and the final nuclear pellet resuspended in $300 \mu \mathrm{l} \mathrm{STM+PMSF}$ containing dithiothreitol $5 \mathrm{mM}, \mathrm{KCl} 0 \cdot 4 \mathrm{M}$ and glycerol $20 \%(\mathrm{v} / \mathrm{v})$. The nuclear suspension was agitated on ice for $15 \mathrm{~min}$ to extract nuclear proteins and centrifuged $\left(2900 \mathrm{~g}, 4^{\circ} \mathrm{C}, 15 \mathrm{~min}\right)$. Supernatants containing nuclear extracts were aliquoted, protein concentrations determined, and stored at $-80^{\circ} \mathrm{C}$.

\section{Protein electrophoresis and Western blotting}

Nuclear proteins (1-20 $\mu \mathrm{g}$ per lane) were separated by SDS/PAGE and electroblotted on to Immobilon P membrane (Millipore Ltd, Watford, Herts, UK) as described (Williams et al. 1994, 1995). Membranes were blocked $\left(1 \mathrm{~h}, 25^{\circ} \mathrm{C}\right)$ in PBS-T (PBS $+0 \cdot 1 \%$ Tween 20; Sigma) containing 20\% (w/v) non-fat milk powder (Marvel; Premier Brands (UK) Ltd, Stafford, Staffs, UK). Filters were incubated overnight at $4{ }^{\circ} \mathrm{C}$ with receptor-specific primary antibodies. $T_{3} R$ antibodies were diluted 1:500 in PBS-T (0.05\%). VDR, RXR and RAR $\alpha$ antibodies were diluted $1: 1000$ in PBS-T (0.05\%) containing 0.25\% BSA. For detection of $T_{3} R$ isoforms, VDR and RXRs, the secondary antibody (horseradish peroxidase-conjugated; Amersham) was diluted 1:75 000 in PBS-T (0.05\%), and for detection of RAR $\alpha$ the secondary antibody was diluted 1:60 000 in PBS-T (0.05\%). Specific receptor proteins were detected by enhanced chemiluminescent assay (ECL; Amersham) after exposure of filters to X-ray film for 1-20 min. Filters were probed with the following primary antibodies: polyclonal against human $T_{3} R \alpha 1$, c-erb $A \alpha 2$ and $T_{3} R \beta 1$ proteins (Macchia et al. 1990, Falcone et al. 1992), polyclonal against rat RAR $\alpha$ (Ali et al. 1992), and monoclonal against human VDR (Pike et al. 1982) (purchased from Cambridge Research Biochemicals, Zeneca, Northwich, UK). A monoclonal antibody against mouse RXR, which recognises the $\alpha, \beta$ and $\gamma$
RXR isoforms (4RX 1D12, (Rochette Egly et al. 1994)), was used to detect RXR protein. Control experiments were included in which primary antibody was omitted and filters were exposed to secondary antibody and ECL detection only. No protein bands were detected in these control experiments using samples derived from cultures containing control or differentiated HL60 cells (data not shown).

\section{Gel mobility-shift assays}

Gel mobility-shift experiments were performed as described (Williams et al. 1991, Brent et al. 1992). Oligonucleotide probes were radiolabelled with $\left[{ }^{32} \mathrm{P}\right] \mathrm{dTTP}$ by Klenow fill-in reactions and column purified. Fresh nuclear protein preparations were prepared from undifferentiated HL60 cells or cells induced to differentiate to monocytes $\left(\mathrm{D}_{3} 5 \mathrm{nM}+9\right.$ cis RA $\left.2.5 \mathrm{nM}\right)$ or neutrophils $\left(\mathrm{D}_{3} 10^{-13} \mathrm{M}+\mathrm{RA} 500 \mathrm{nM}\right)$ for analysis in gel shifts. The absence or presence of cell differentiation was confirmed in each culture before nuclear protein preparation. Nuclear extracts were not supplemented with additional hormone during gel shift analysis. Labelled probe (375 c.p.m.) was incubated at room temperature for $30 \mathrm{~min}$ with $5 \mu \mathrm{g}$ nuclear protein from undifferentiated or hormone-treated cells in $30 \mu \mathrm{l}$ reaction mixtures in the presence of $200 \mu \mathrm{g} / \mathrm{ml}$ poly(dI-dC) (Pharmacia), $20 \mathrm{mM}$ HEPES, $\mathrm{pH} 7 \cdot 8,50 \mathrm{mM} \mathrm{KCl}, 1 \mathrm{mM}$ dithiothreitol, $5 \mu \mathrm{g}$ BSA (Fraction V; Sigma) and 20\% glycerol. Competition incubations contained 25-1000-fold molar excess of unlabelled competitor oligonucleotide. Antibody studies involved addition of $2.5 \mu \mathrm{l}$ of appropriate antibody to binding reaction mixtures $15 \mathrm{~min}$ before co-incubation with oligonucleotide probe for a further $30 \mathrm{~min}$. Reaction products were resolved by non-denaturing PAGE $(200 \mathrm{~V}$ at $4{ }^{\circ} \mathrm{C}$ ). The $5 \%$ Tris/borate/EDTA (TBE) gels were prerun for $90 \mathrm{~min}$ at $4{ }^{\circ} \mathrm{C}$ in $1 \times \mathrm{TBE}$ buffer before loading. Gels were dried under vacuum and autoradiographed at $-70{ }^{\circ} \mathrm{C}$ overnight.

\section{Oligonucleotide sequences}

Double-stranded oligonucleotides were synthesised with BamHI restriction site overhangs at each end and contained two perfect AGGTCA motifs arranged in a direct repeat configuration (DR) and separated by 1, 3, 4 or 5 spacer nucleotides to give the following sequences: DR+1: 5' TCAGGTCAGAGGTCAGAG 3'; DR+3: 5' TCAGGTCAAGGAGGTCAGAG 3'; DR +4: 5' TCAGGTCACAGGAGGTCAGAG $3^{\prime}$; and DR +5: $5^{\prime}$ TCAGGTCAAGAGCAGgTCAGAG $3^{\prime}$. The DR +1 , $\mathrm{DR}+3, \mathrm{DR}+4$ and $\mathrm{DR}+5$ oligonucleotides contain consensus idealised RXRE, VDRE, $T_{3} R E$ and RARE sequences respectively (Umesono et al. 1991, Zechel et al. 1994, Katz et al. 1995). An oligonucleotide derived from the proximal promoter region of the human $\gamma$ globin gene was used as a non-specific competitor and contained the 
following sequence: $5^{\prime}$ TCCAGTGAGGCCAGGGGCC GGCGGCTGGCTAGGGATGA 3' (Cunningham et al. 1994).

\section{Statistical analysis}

Analyses of the linear quantifications of receptor expression in Western blots were performed using Cricket Graph III computer software (Computer Associates, Slough, Berks, UK). Changes in expression of receptor proteins are presented graphically as mean \pm S.E.M. receptor level in differentiated cells relative to standardised controls derived from untreated undifferentiated HL60 cells. All experiments were performed on at least three separate occasions. All values were corrected relative to the total nuclear protein concentration in each individual extract. Statistical analysis was performed using an Instat v2.04a computer program (GraphPad Software, San Diego, CA, USA). Group and multiple comparisons were analysed initially by ANOVA. When statistical differences were obtained they were analysed further by Tukey-Kramer Multiple Comparison post tests.

\section{Results}

\section{Hormone induction of HL60 cell differentiation}

Treatment of HL60 cells with the following hormone combinations $\left(\mathrm{D}_{3}(5 \mathrm{nM})+9\right.$ cisRA $(2 \cdot 5 \mathrm{nM}) ; \mathrm{D}_{3}(5 \mathrm{nM})$ + RA (10 nM); $\mathrm{D}_{3}(50 \mathrm{nM}) ; \mathrm{KH} 1060(0 \cdot 3 \mathrm{nM}) ; \mathrm{EB} 1089$ $(1 \cdot 25 \mathrm{nM})$; KH1060 (0.3 nM) + RA (10 nM); EB1089 $(1.25 \mathrm{nM})+\mathrm{RA}(10 \mathrm{nM}))$ resulted in differentiation of $80-90 \%$ of HL60 cells to mature monocytes. Treatment with RA (500 nM) or $\mathrm{D}_{3}\left(10^{-13} \mathrm{M}\right)+\mathrm{RA}(500 \mathrm{nM})$ resulted in differentiation of $20-30 \%$ or $58-72 \%$ of HL60 cells respectively to mature neutrophils (data not shown). These data, derived from three separate experiments, are consistent with previous studies which defined optimal conditions for monocyte (Brown et al. 1994) and neutrophil (Bunce et al. 1995) differentiation of HL60 cells.

Treatment of HL60 cells with $\mathrm{T}_{3}$ alone $(1 \mathrm{nM}$ or $100 \mathrm{nM}$ ) did not induce differentiation along either lineage. Treatment of cells with $\mathrm{D}_{3}(5 \mathrm{nM})+9$ cisRA $(2 \cdot 5 \mathrm{nM})$ or $\mathrm{D}_{3}(5 \mathrm{nM})+\mathrm{RA}(10 \mathrm{nM})$ in the presence of $\mathrm{T}_{3}(1$ or $100 \mathrm{nM}$ ) resulted in differentiation of $78-94 \%$ of cells to mature monocytes; and treatment with RA $(500 \mathrm{nM})$ or $\mathrm{D}_{3}\left(10^{-13} \mathrm{M}\right)+\mathrm{RA}(500 \mathrm{nM})$ in the presence of $\mathrm{T}_{3}$ (1 or $100 \mathrm{nM}$ ) resulted in differentiation of $24-29 \%$ or $62-76 \%$ of cells respectively to mature neutrophils (data not shown). The data, derived from three separate experiments, clearly indicate that $\mathrm{T}_{3}$ did not influence $\mathrm{D}_{3^{-}}$or retinoid-induced HL60 cell differentiation.

\section{Receptor protein expression and quantitative detection in HL60 cells}

Undifferentiated and hormone-induced HL60 cells expressed the following receptor proteins: VDR $(57 \mathrm{kDa})$,
RXR (67 kDa), RAR $\alpha(49 \mathrm{kDa}), \mathrm{T}_{3} \mathrm{R} \alpha 1$ (48 kDa), c-erb $\mathrm{A} \alpha 2(58 \mathrm{kDa})$ and $\mathrm{T}_{3} \mathrm{R} \beta 1(62 \mathrm{kDa})$. There was no change in receptor protein size after induction of cell differentiation by hormones (data not shown). Estimation of the approximate molecular masses of each protein using standard markers indicated that the expressed receptors were of appropriate size (Pike et al. 1982, Macchia et al. 1990, Ali et al. 1992, Falcone et al. 1992, Rochette Egly et al. 1994). The $4 \mathrm{RX} 1 \mathrm{D} 12$ monoclonal antibody used to detect RXR expression recognises the three RXR isoforms $\alpha, \beta$ and $\gamma$ (Rochette Egly et al. 1994). Previous studies have shown that HL60 cells express a full-length mRNA encoding RXR $\alpha$, a truncated mRNA that is $\operatorname{RXR} \beta$-specific but no $\operatorname{RXR} \gamma$ transcript (Brown et al. 1994), whilst other workers have shown that $\operatorname{RXR} \alpha$ is the only detectable RXR protein in HL60 nuclear extracts using isoform-specific antibodies in Western blots (Titcomb et al. 1994). The $67 \mathrm{kDa} \mathrm{RXR}$ protein detected in these studies is therefore likely to represent RXR $\alpha$ and is appropriately sized (Titcomb et al. 1994). In order to determine the relative levels of expression of individual receptors, the linear range for the detection of receptors using each antibody was determined (Fig. 1) as described previously for $\mathrm{T}_{3} \mathrm{R}$ in osteosarcoma cells (Williams et al. 1994). Thus the relative levels of expression of each receptor could be compared quantitatively between control and hormone-treated cells.

\section{Hormone receptor expression in monocyte-differentiated HL60 cells}

We have previously shown that synergy between $\mathrm{D}_{3}$ or synthetic analogues of $\mathrm{D}_{3}$ (KH1060, EB1089) and retinoids (RA or 9cisRA) results in an increased sensitivity of proliferating HL60 cells to the induction of monocyte differentiation (Brown et al. 1994). A variety of hormone combinations were used to induce monocyte differentiation, and relative levels of expression of VDR, RXR, RAR and $T_{3} R$ proteins were compared between each treatment group and undifferentiated control cells (Fig. 2). The changes in receptor expression seen in monocytedifferentiated cells compared with controls were consistent irrespective of hormone treatment. Thus in monocytedifferentiated cells, expression of VDR and RXR proteins was unchanged whilst expression of RAR and $T_{3} R$ was markedly reduced (Fig. 2). Levels of expression of RAR $\alpha$ and VDR were also determined during the induction of terminal monocyte differentiation at $0-5$-day time points after the initiation of treatment with $\mathrm{D}_{3}$ $50 \mathrm{nM}$. In these studies, RAR $\alpha$ expression gradually decreased with time (Fig. 3A and D), whilst the percentage of monocyte-differentiated cells present in the cultures increased (Fig. 3B and D) and correlated negatively with RAR $\alpha$ expression (Fig. 3C). Expression of VDR was unchanged throughout the period of induction of differentiation (Fig. 3D). 
TR- $\beta 1$

A
VDR
$r^{2}=0.98$
RXR
$r^{2}=0.98$
RAR $\alpha$
$r^{2}=0.98$
$T R \alpha 1$
$r^{2}=0.95$
$c-e r b$ A $\alpha 2$
$r^{2}=0.91$

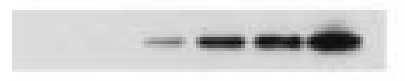

B
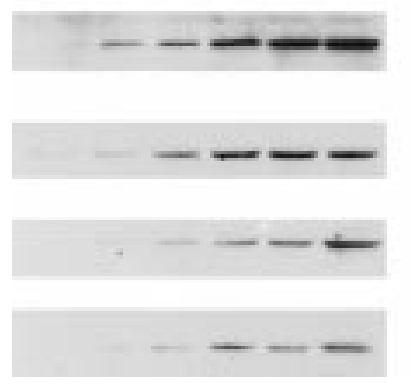

$\begin{array}{llllll}1 & 2.5 & 5 & 10 & 15 & 20\end{array}$

Protein Concentrations $(\mu \mathrm{g})$

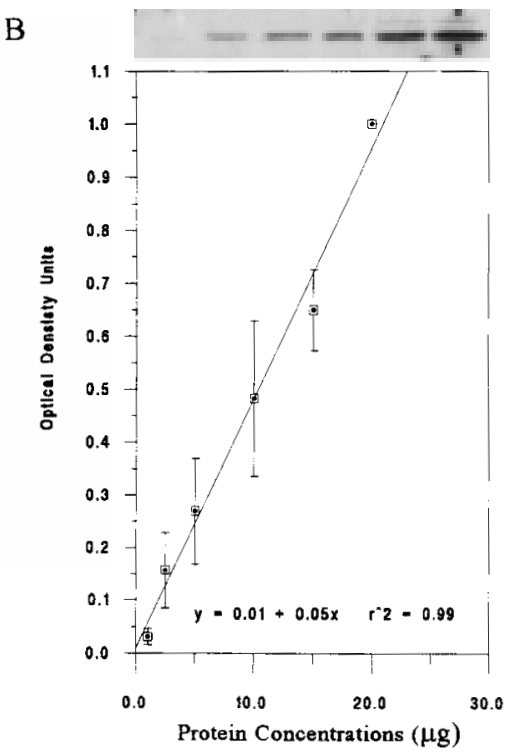

Figure 1 Quantitative detection of receptor protein expression. Western blots showing VDR (57 kDa), RXR (67 kDa), RAR $\alpha$ (49 kDa), $T_{3} R \alpha 1$ (48 kDa), c-erb A $\alpha 2$ (58 kDa) and $T_{3} R \beta 1$ (62 kDa) protein expression in nuclear extracts prepared from HL60 cells. Increasing concentrations $(1-20 \mu \mathrm{g})$ of nuclear protein were examined for expression of the various receptors, and resulting Western blots were quantified by laser densitometry. Data from three identical experiments were plotted in optical density units versus nuclear protein concentration $(\mu \mathrm{g})$ to determine whether detection of receptor proteins was linear. An example is shown for quantification of $T_{3} R \beta 1$ in (B). Lines of best fit were calculated using Cricket Graph III computer software, and correlation coefficients $\left(r^{2}\right)$ are given for quantification of each receptor. A concentration of nuclear protein $(10 \mu \mathrm{g})$ in the middle of the linear range was selected for subsequent experiments.

\section{Hormone receptor expression in neutrophil-differentiated HL60 cells}

Recently, we showed that induction of HL60 cell differentiation to neutrophils or monocytes can be specified by subtle variations in the ratio of retinoids to $D_{3}$. High concentrations of $\mathrm{D}_{3}$ relative to retinoids resulted in monocyte differentiation whilst a reciprocal ratio of $\mathrm{D}_{3}$ to retinoid resulted in the promotion of neutrophil differentiation (Bunce et al. 1995). Combinations of hormones were used to induce neutrophil differentiation of HL60 cells in parallel with an undifferentiated control group and a group of cells induced to differentiate to monocytes for comparison. In monocyte-differentiated cells (Fig. 4, lane 4), as before, expression of VDR and RXR proteins was unchanged relative to control undifferentiated cells (lane 1) whilst expression of RAR and $T_{3} R$ proteins was markedly reduced. Changes in receptor expression shown in neutrophil-differentiated cells (lanes 2 and 3) were consistent irrespective of hormone treatment. Thus, in neutrophil-differentiated cells, expression of VDR was markedly reduced relative to controls whilst expression of RAR, $\mathrm{T}_{3} \mathrm{R}$ and $\mathrm{RXR}$ proteins was unchanged (Fig. 4).
Effect of $\mathrm{T}_{3}$ on hormone receptor expression in differentiated HL60 cells

$\mathrm{T}_{3}$ did not induce differentiation of HL60 cells or modify induction of differentiation in response to any combinations of $\mathrm{D}_{3}$ and retinoids. Furthermore, $\mathrm{T}_{3}(100 \mathrm{nM})$ did not alter the changes in expression of any receptors seen in response to $\mathrm{D}_{3}$ or retinoids. Thus, in monocytedifferentiated cells (Fig. 5, lanes A, D and E), expression of VDR and RXR was unchanged but expression of RAR and $T_{3} R$ was reduced relative to undifferentiated control (lane $\mathrm{B}$ ) or $\mathrm{T}_{3}$-treated (lane $\mathrm{C}$ ) cells; in neutrophildifferentiated cells (lanes F and G) expression of VDR was reduced but expression of $R A R, T_{3} R$ and $R X R$ was unchanged relative to undifferentiated control or $\mathrm{T}_{3}$-treated cells.

Interaction of nuclear proteins from control and differentiated HL60 cells with hormone response elements

We next investigated whether the changes in receptor stoichiometry correlated with differences in how nuclear proteins interact with DNA. Nuclear extracts from control, monocyte- and neutrophil-differentiated HL60 cells 

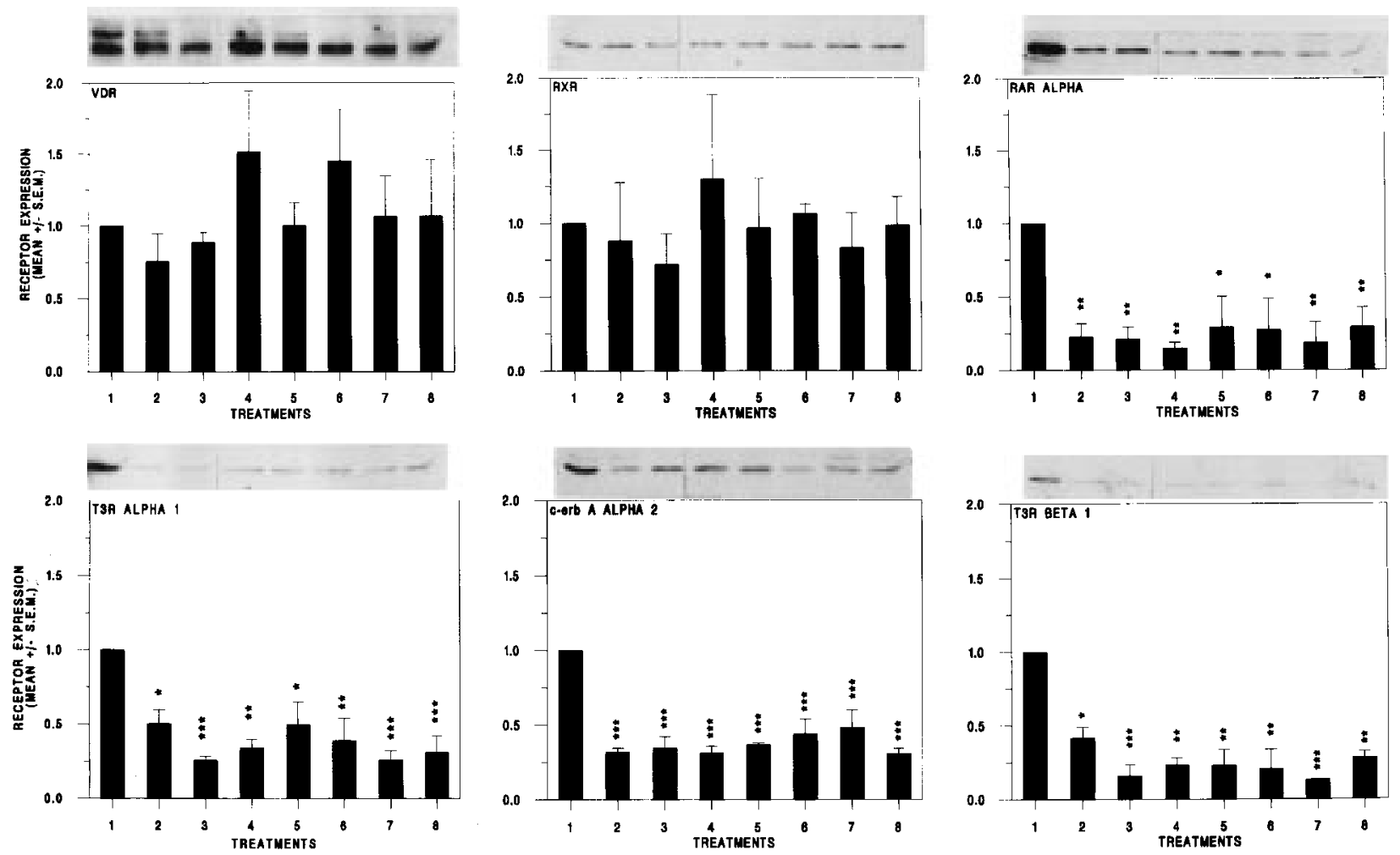

Figure 2 Expression of nuclear receptor proteins in monocyte-differentiated HL60 cells. Expression of VDR, RXR, RAR $\alpha, T_{3} R \alpha 1, c-e r b$ A $\alpha 2$ and $T_{3} R \beta 1$ proteins in nuclear proteins $(10 \mu \mathrm{g} /$ lane) from monocyte-differentiated HL60 cells was determined in Western blots and quantified by laser densitometry of autoradiographs. The data from three or four experiments are shown relative to standardised control undifferentiated cells in graphs plotted below a representative Western blot from a single experiment. Treatments resulting in monocyte differentiation (lanes 2-8) are shown on the $x$-axis (lane 1, control; 2, $\mathrm{D}_{3} 5 \mathrm{nM}+9$ cisRA 2.5 nM; $3 \mathrm{D}_{3} 5 \mathrm{nM}+\mathrm{RA} 10 \mathrm{nM}$; $4 \mathrm{D}_{3} 50 \mathrm{nM}$; 5 KH1060 0.3 nM; 6 EB1089 1.25 nM; 7 KH1060 0.3 nM + RA 10 nM; 8 EB1089 1.25 nM + RA 10 nM), and mean \pm S.E.M. receptor expression relative to control undifferentiated cells is shown on the $y$-axis. Statistical analysis was by ANOVA and Tukey-Kramer post tests; ${ }^{*} P<0 \cdot 05,{ }^{*} P<0 \cdot 01,{ }^{*} * * P<\cdot 001$ compared with control.

were incubated with consensus DNA-binding sites for RXR (DR+1), VDR (DR+3) and RAR (DR+5) (Umesono et al. 1991, Zechel et al. 1994, Katz et al. 1995) in gel mobility-shift assays.

Control nuclear extracts formed two major specific complexes with VDRE, RARE and RXRE sequences that were not competed for by addition of 100 -fold molar excess of unlabelled non-specific oligonucleotide (Fig. 6A, lanes 1 and 2, 6 and 7, 11 and 12) but were efficiently competed for by a 100-fold excess of the unlabelled response element (Fig. 6A, lanes 3, 8 and 13). Crosscompetition experiments revealed that complexes bound to the VDRE were not competed for by either the RXRE or RARE, those bound to the RARE were incompletely competed for by RXRE but were competed for by the VDRE, and those bound to the RXRE were incompletely competed for by the VDRE but were competed for by the RARE (Fig. 6A, lanes 4 and 5, 9 and 10, 14 and 15).

Monocyte nuclear extracts also formed two major specific complexes. These were not competed for by addition of 100-fold molar excess of unlabelled nonspecific oligonucleotide (Fig. 6B, lanes 1 and 2, 6 and 7, 11 and 12) but were competed for by a 100-fold excess of the unlabelled response element (Fig. 6B, lanes 3, 8 and 13). Complete competition of binding of complexes to the RXRE by unlabelled RXRE competitor required a 250-fold molar excess (not shown). In cross-competition experiments, complexes bound to the VDRE were not competed for by the RXRE but were competed for by the RARE, those bound to the RARE were incompletely competed for by the RXRE but efficiently competed for by the VDRE, and those bound to the RXRE were competed for by both the VDRE and RARE (Fig. 6B, lanes 4 and 5, 9 and 10, 14 and 15), although complete competition by the RARE required a 250 -fold molar excess (not shown).

Neutrophil nuclear extracts formed three specific complexes. These were not competed for by addition of $100-$ fold molar excess of unlabelled non-specific oligonucleotide (Fig. 6C, lanes 1 and 2, 6 and 7, 11 and 12) but were competed for by a 100 -fold excess of the unlabelled 

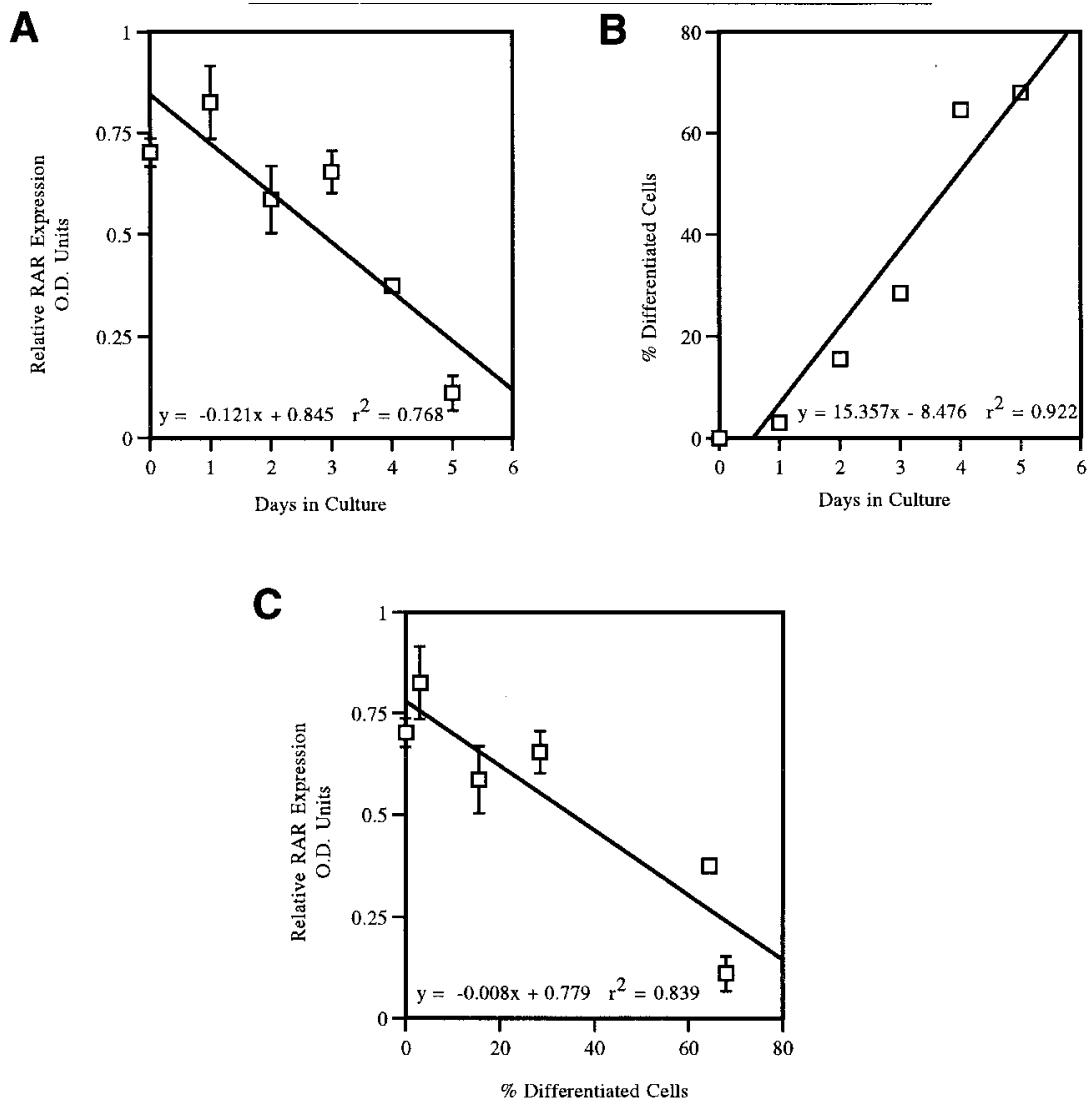

\begin{tabular}{|c|c|c|c|}
\hline Day & \multicolumn{1}{l|}{ RAR } & VDR & \% Diff \\
\hline $\mathbf{0}$ & $0.70+/-0.03$ & $0.81+/-0.15$ & 0.0 \\
\hline $\mathbf{1}$ & $0.83+/-0.09$ & $1.01+/-0.10$ & 3.0 \\
\hline $\mathbf{2}$ & $0.59+/-0.08$ & $1.03+/-0.29$ & 15.5 \\
\hline $\mathbf{3}$ & $0.65+/-0.05$ & $0.89+/-0.07$ & 28.5 \\
\hline $\mathbf{4}$ & $0.37+/-0.01$ & $0.79+/-0.16$ & 64.5 \\
\hline $\mathbf{5}$ & $0.11+/-0.04$ & $0.99+/-0.19$ & 68.0 \\
\hline
\end{tabular}

Figure 3 Expression of RAR $\alpha$ and VDR proteins in HL60 cells harvested at sequential time points after the onset of induction of monocyte differentiation. Expression of RAR $\alpha$ and VDR proteins in nuclear proteins $(10 \mu \mathrm{g} / \mathrm{lane})$ from differentiating HL60 cell cultures (harvested at $0,1,2,3,4$ and 5 days after initiation of treatment with $50 \mathrm{nM} \mathrm{D}_{3}$ to induce monocyte differentiation) was determined in Western blots and quantified by laser densitometry of autoradiographs. Receptor expression data from three inductions are shown relative to standardised untreated control HL60 cells for each time point and expressed as optical density units (mean \pm S.E.M.). The percentage of differentiated cells in each culture was determined by measurement of the proportion of cells that could phagocytose complement-coated yeast. Expression of RAR $\alpha$ (A) and \% differentiated cells (B) are plotted versus the number of days of HL60 cell culture after initiation of treatment with $D_{3}(50 \mathrm{nM})$; expression of RAR $\alpha$ is plotted versus \% differentiated cells in (C). In each case the line of best fit was calculated; the linear regression equation and correlation coefficient values $\left(r^{2}\right)$ are given for each analysis. The relative levels of RAR $\alpha$ and VDR expression (together with the percentage of differentiated cells) are given for each day of cell culture after initiation of $D_{3}$ treatment in (D). 

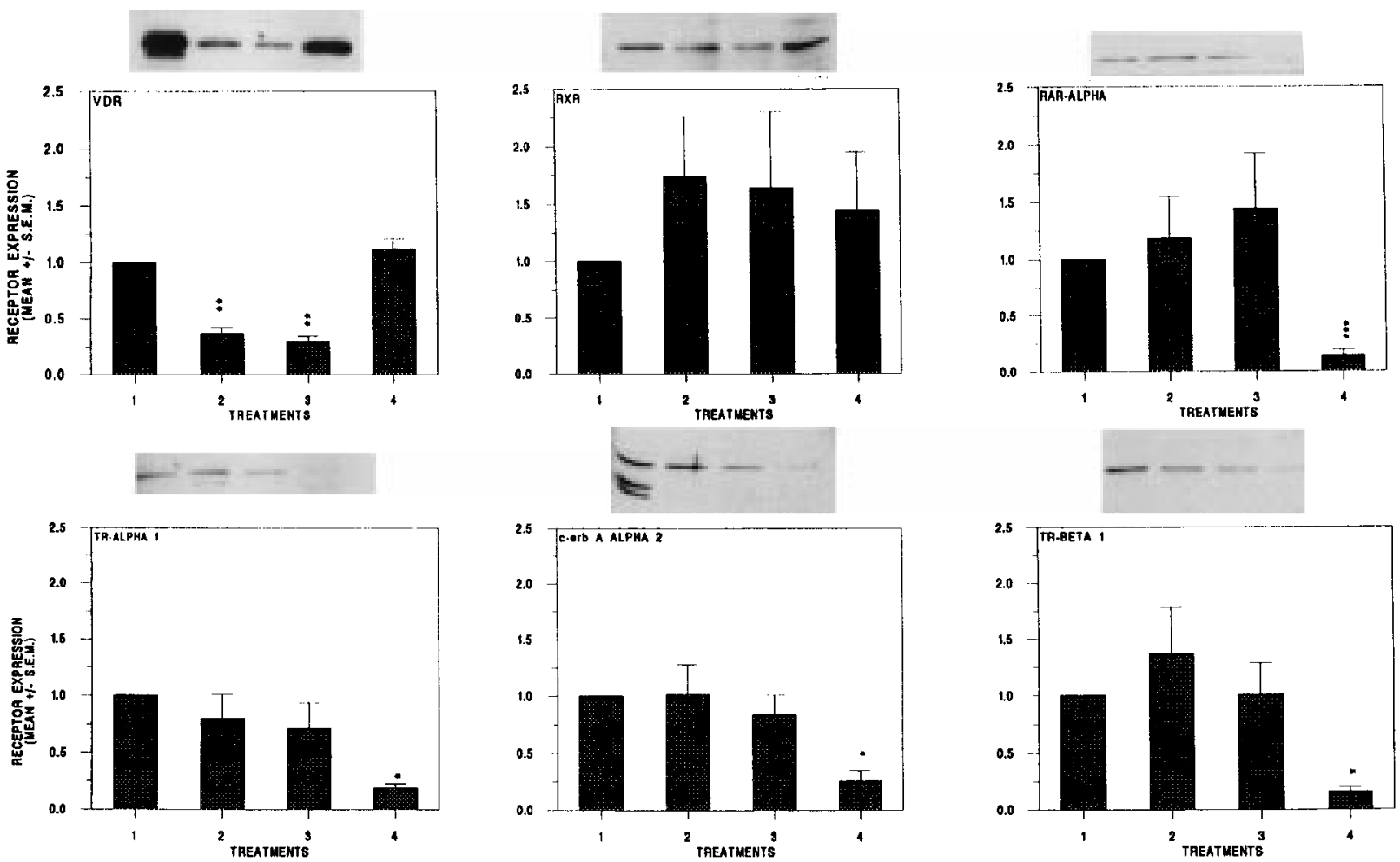

Figure 4 Expression of nuclear receptor proteins in neutrophil- and monocyte-differentiated HL60 cells. Expression of VDR, RXR, RAR $\alpha$, $T_{3} R \alpha 1$, c-erb $A \alpha 2$ and $T_{3} R \beta 1$ proteins in nuclear proteins $(10 \mu \mathrm{g} /$ lane) from neutrophil- and monocyte-differentiated HL60 cells was determined in Western blots and quantified by laser densitometry of autoradiographs. The data from three or four experiments are shown relative to standardised control undifferentiated cells in graphs plotted below a representative Western blot from a single experiment. Treatments resulting in neutrophil (lanes 2 and 3) or monocyte (lane 4) differentiation are shown on the $x$-axis (lane 1 , control; 2, $\mathrm{D}_{3} 10^{-13} \mathrm{M}+\mathrm{RA} 500 \mathrm{nM} ; 3$, RA $500 \mathrm{nM} ; 4, \mathrm{D}_{3} 5 \mathrm{nM}+$ 9cisRA $2.5 \mathrm{nM}$ ), and mean \pm s.E.M. receptor expression relative to control undifferentiated cells is shown on the $y$-axis. Statistical analysis was by ANOVA and Tukey-Kramer post tests; ${ }^{*} P<0 \cdot 05$, ${ }^{* *} P<0 \cdot 01,{ }^{* * *} P<0 \cdot 001$ compared with control.

response element (Fig. 6C, lanes 3, 8 and 13). In crosscompetition experiments, complexes bound to the VDRE were not competed for by the RXRE but the lower of the three complexes was competed for by the RARE, those bound to the RARE were incompletely competed for by RXRE but were efficiently competed for by the VDRE, and those bound to the RXRE were competed for by both the VDRE and RARE (Fig. 6C, lanes 4 and 5, 9 and 10, 14 and 15).

\section{Effect of receptor antibodies on nuclear protein/DNA complexes}

Gel mobility-shift experiments were performed in the presence of receptor antibodies to characterise nuclear protein/DNA complexes further. Since monocyte differentiation correlated with VDR signalling and neutrophil differentiation with retinoid signalling, nuclear extracts from monocytes were investigated with the use of VDRE and RXRE probes and extracts from neutrophils with RARE and RXRE probes.
As previously, monocyte extracts formed two major complexes with the VDRE and RXRE sequences. Complex formation with the VDRE was inhibited by co-incubation with VDR antibody but was unaffected by the RXR or RAR antibodies (Fig. 7A, lanes 1-4). In contrast, complex formation with the RXRE was partially inhibited (lower complex abolished, upper complex enhanced) by the RXR antibody but unaffected by the VDR or RAR antibodies (Fig. 7B, lanes 1-4).

Neutrophil extracts formed three major complexes with the RARE and RXRE sequences as before. Complex formation with the RARE was partially inhibited by co-incubation with RAR and RXR antibodies (only the upper complex remained) but was unaffected by the VDR antibody (Fig. 7A, lanes 5-12). Similarly, complex formation with the RXRE was also partially inhibited by co-incubation with RAR and RXR antibodies but was unaffected by the VDR antibody (Fig. 7B, lanes 5-8). Only the middle complex remained in the presence of RXR antibody and both lower complexes remained with RAR antibody. 

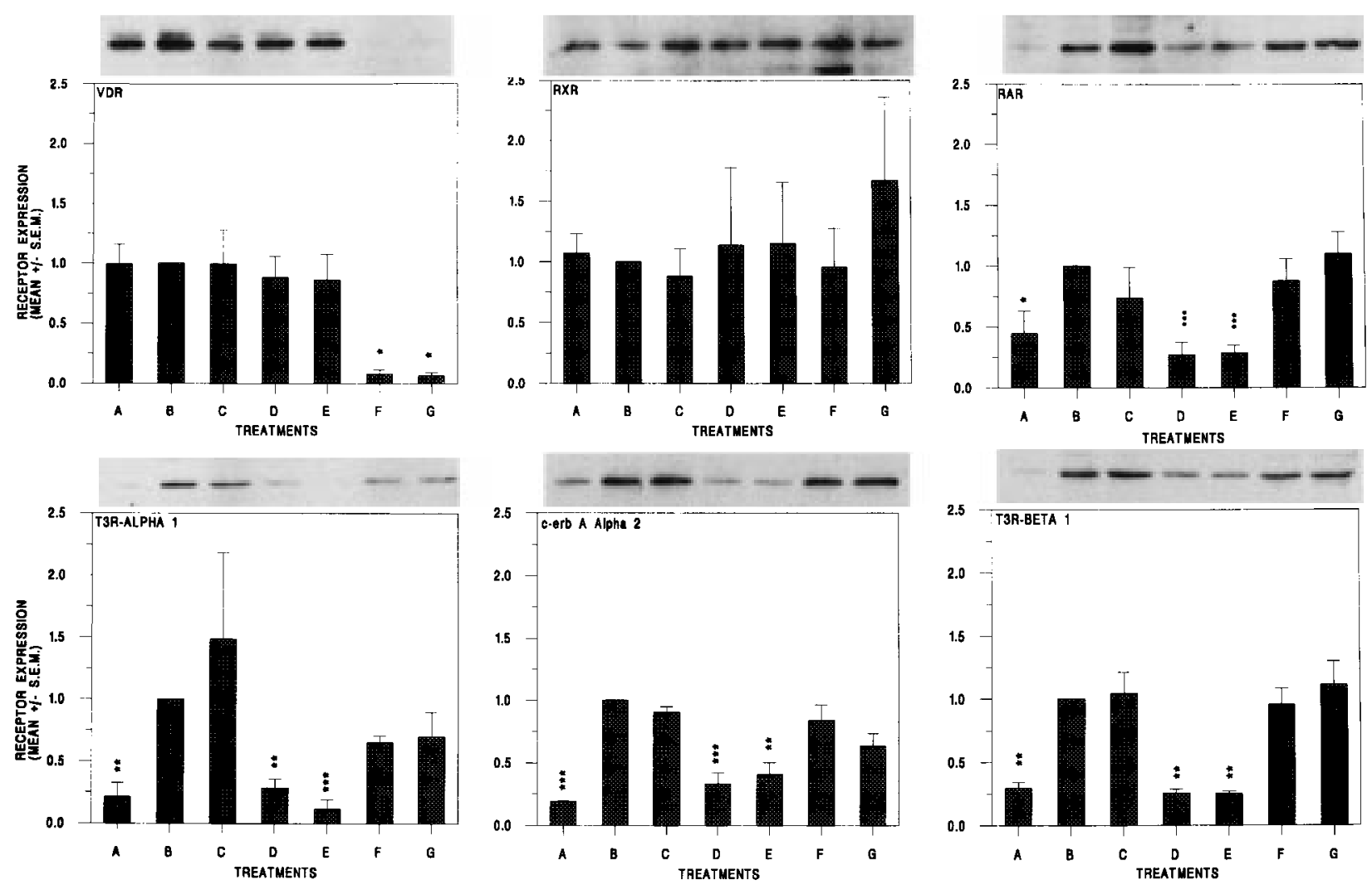

Figure 5 Expression of nuclear receptor proteins in HL60 cells induced to differentiate in the presence of $\mathrm{T}_{3}$. Expression of VDR, RXR, $R A R \alpha, T_{3} R \alpha 1$, c-erb $A \alpha 2$ and $T_{3} R \beta 1$ proteins in nuclear proteins $(10 \mu \mathrm{g} /$ lane) from monocyte- and neutrophil-differentiated HL60 cells in the presence of $\mathrm{T}_{3}$ was determined in Western blots and quantified by laser densitometry of autoradiographs. The data from three or four experiments are shown relative to standardised control undifferentiated cells in graphs plotted below a representative Western blot from a single experiment. Treatments resulting in monocyte (lanes $\mathrm{A}, \mathrm{D}$ and $\mathrm{E}$ ) or neutrophil (lanes $\mathrm{F}$ and $\mathrm{G}$ ) differentiation are shown on the $x$-axis (lane $A, D_{3} 5 \mathrm{nM}+9$ cisRA $2.5 \mathrm{nM}$; B, control; C, $T_{3} 100 \mathrm{nM} ; \mathrm{D}, \mathrm{D}_{3} 5 \mathrm{nM}+9$ cisRA 2.5 nM + T $100 \mathrm{nM} ; \mathrm{E}, \mathrm{D}_{3} 5 \mathrm{nM}+\mathrm{RA} 10 \mathrm{nM}$ $+\mathrm{T}_{3} 100 \mathrm{nM} ; \mathrm{F}, \mathrm{D}_{3} 10^{-13} \mathrm{M}+\mathrm{RA} 500 \mathrm{nM}+\mathrm{T}_{3} 100 \mathrm{nM} ; \mathrm{G}, \mathrm{RA} 500 \mathrm{nM}+\mathrm{T}_{3} 100 \mathrm{nM}$ ), and mean \pm s.E.M. receptor expression relative to control undifferentiated cells is shown on the $y$-axis. Statistical analysis was by ANOVA and Tukey-Kramer post tests; ${ }^{*} P<0 \cdot 05,{ }^{* *} P<0 \cdot 01$, $* * * P<0 \cdot 001$ compared with control.

\section{Discussion}

We have characterised the nuclear receptor profiles in HL60 cells induced to terminally differentiate to monocytes or neutrophils by $\mathrm{D}_{3}$ or retinoids (Collins et al. 1977, Breitman et al. 1980). We demonstrated that HL60 cells express VDR, RAR $\alpha$, RXR, $\mathrm{T}_{3} \mathrm{R} \alpha 1$, c-erb A $\alpha 2$ and $\mathrm{T}_{3} \mathrm{R} \beta 1$ proteins and therefore possess all the necessary components required for convergent $D_{3}$, retinoid and $T_{3}$ signalling pathways (Kliewer et al. 1992, Leid et al. 1992, Rosen et al. 1993, Glass 1994, Schrader et al. 1994, Williams 1994, Katzenellenbogen et al. 1996). Although our data support the concept that activation of RXR heterodimers containing either VDR or RAR is associated with hormone-induced monocyte or neutrophil differentiation respectively, the mechanisms whereby this may be achieved are unexpected.

HL60 cells were induced to differentiate to monocytes using several optimised combinations of $\mathrm{D}_{3}$, synthetic $\mathrm{D}_{3}$ analogues and retinoids (Brown et al. 1994, Bunce et al. 1995). Regardless of the combination of hormones used, levels of VDR and RXR proteins were unchanged whilst expression of RAR and $T_{3} R$ proteins was markedly reduced in monocyte-differentiated cells compared with controls. This stoichiometric change results in an increased ratio of VDR and RXR relative to RAR and $T_{3} R$. We propose that this change would reduce competition for RXR from RAR and $T_{3} R$ and favour VDR/RXR heterodimerisation in hormone-induced monocytedifferentiated cells. In contrast, in retinoid-induced neutrophil-differentiated cells, there were no changes in the levels of expression of RAR, RXR and $T_{3} R$ proteins regardless of hormone treatment whereas expression of VDR was markedly reduced relative to controls. Thus induction of neutrophil differentiation correlates with alteration of the stoichiometry between VDR, RAR, $\mathrm{RXR}$ and $\mathrm{T}_{3} \mathrm{R}$ in favour of RAR, RXR and $\mathrm{T}_{3} \mathrm{R}$. This shift in equilibrium is predicted to optimise formation of 

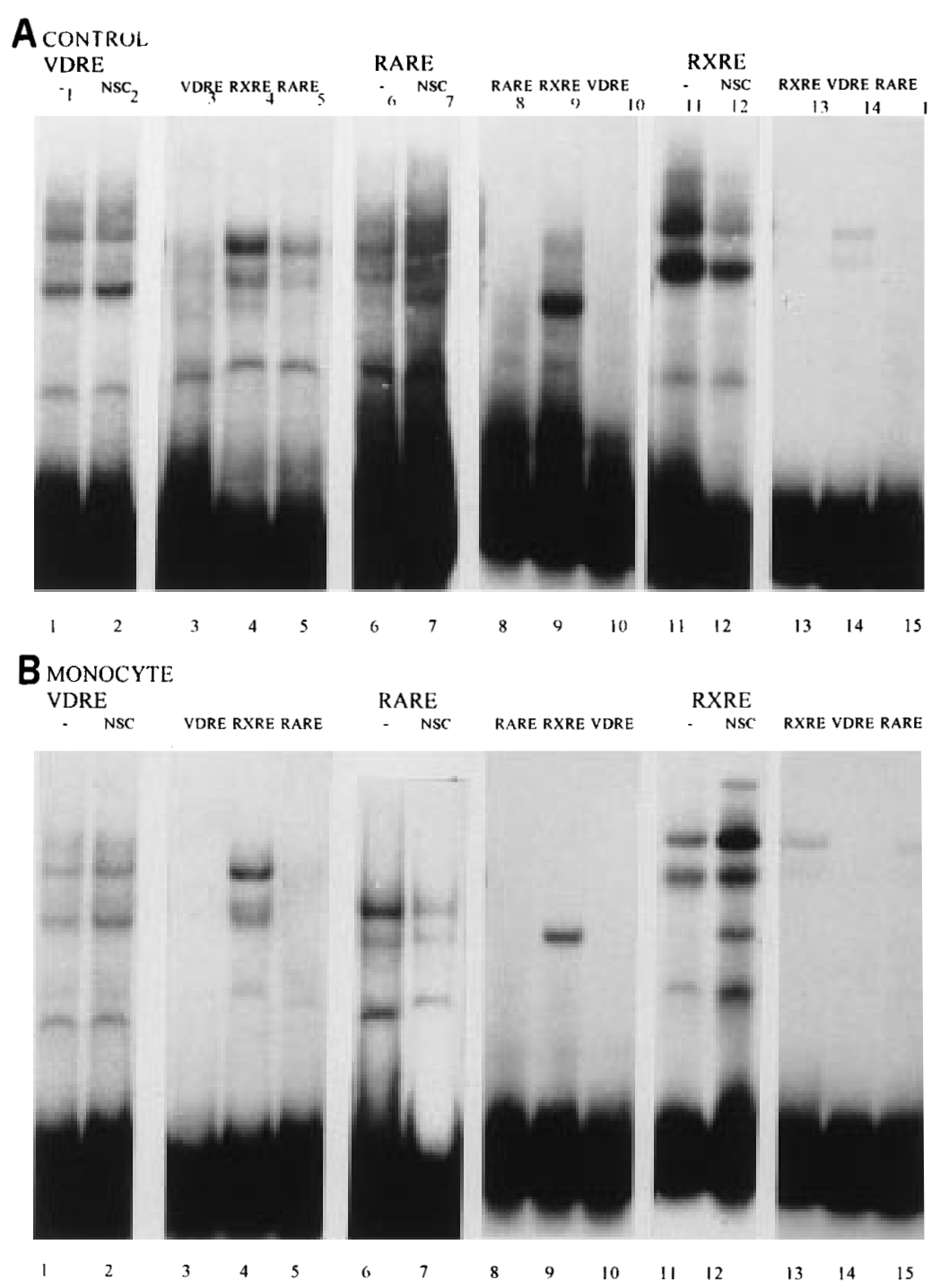

\section{NEUTROPHIL VDRE}

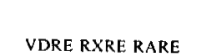

$$
\begin{array}{llll}
\text { RARE } & \multicolumn{2}{c}{\text { RXRE }} \\
-\quad \text { NSC } & \text { RARE RXRE VDRE } & - & \text { NSC } \\
& & &
\end{array}
$$
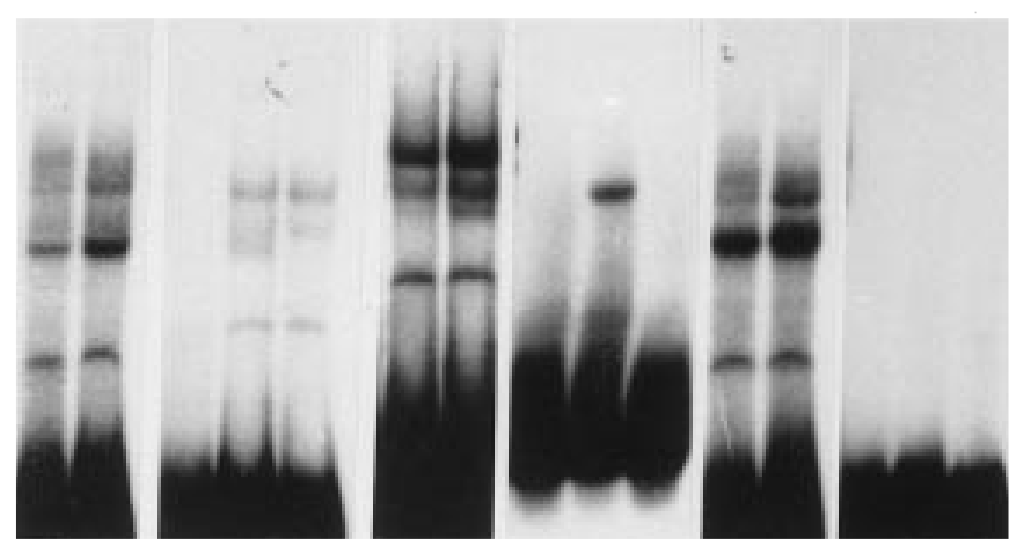

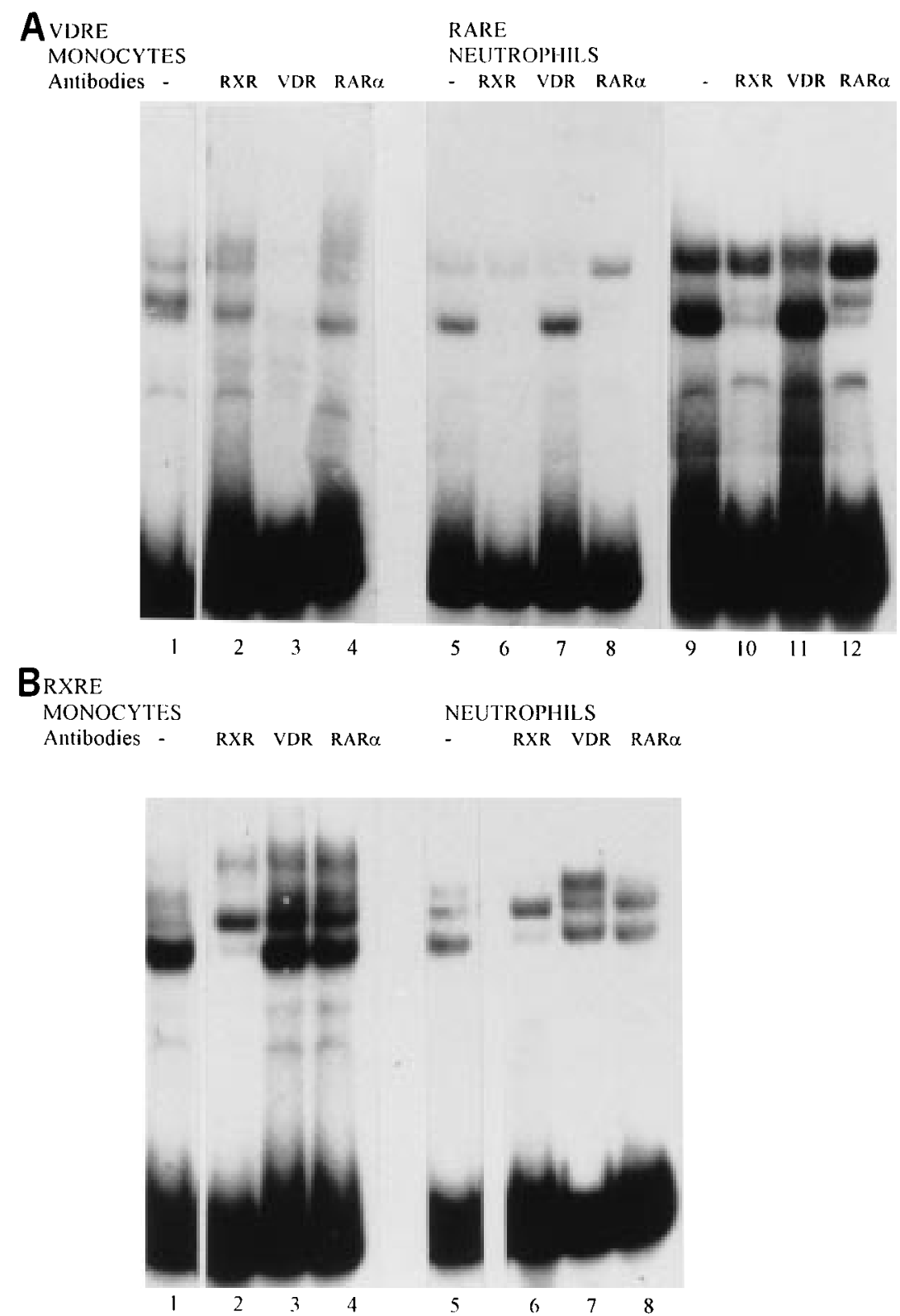

Figure 7 Effect of receptor antibodies on formation of nuclear protein/DNA complexes. Gel mobility-shift assay analysis of nuclear proteins ( $5 \mu \mathrm{g} / \mathrm{lane})$ from monocytedifferentiated HL60 cells incubated with a ${ }^{32}$ P-labelled VDRE (A; lanes 1-4) or RXRE (B; lanes 1-4) oligonucleotide (375 c.p.m./lane) and from neutrophil-differentiated HL60 cells incubated with an RARE (A; lanes 5-12) or RXRE (B; lanes 5-8) oligonucleotide. Binding to the RARE in (A), lanes 5-8 and 9-12 is shown as short and longer exposures of the same gel. The effect of addition of $2.5 \mu \mathrm{l}$ receptor-specific antibodies (RXR, VDR, RAR) to incubation mixtures before electrophoretic separation is shown in A (lanes $2-4,6-8$ and 10-12) and B (lanes 2-4 and 6-8).

Figure 6 Interaction of nuclear proteins from control and differentiated HL60 cells with hormone response elements. Nuclear proteins $\left(5 \mu \mathrm{g} /\right.$ lane) from control undifferentiated (A), monocyte- (B) and neutrophil- (C) differentiated HL60 cells were incubated with ${ }^{32} \mathrm{P}$-labelled VDRE (lanes 1-5), RARE (lanes 6-10) and RXRE (lanes 11-15) oligonucleotides (375 c.p.m./lane) and analysed in gel mobility-shift assays. The effect of addition of 100-fold molar excess of a non-specific (NSC), VDRE, RARE or RXRE competitor oligonucleotide to incubation reactions before electrophoretic separation is shown in lanes $2-5,7-10$ and $12-15$ in each panel. 
$\mathrm{RAR} / \mathrm{RXR}$ heterodimers at the expense of VDRcontaining complexes. The maintenance of $\mathrm{T}_{3} \mathrm{R}$ concentrations during neutrophil differentiation suggests that formation of $T_{3} R / R X R$ heterodimers is not compromised during this process.

Because of this, and the possibility that $\mathrm{T}_{3} \mathrm{R}$ may heterodimerise with VDR (Schrader et al. 1994) and RAR (Glass et al. 1989) in addition to RXR (Kliewer et al. 1992), we investigated the effects of $T_{3}$ in this system. These experiments conclusively demonstrated that $\mathrm{T}_{3}$ does not influence differentiation of HL60 cells towards either the monocyte or neutrophil lineage and does not modify nuclear receptor expression. In this regard it is important to note that HL60 cells were maintained serum-free in long-term cultures and all experiments were performed under serum-free conditions. In contrast, previous studies on HL60 cells (Ballerini et al. 1991) and peripheral blood monocytes (Mooij et al. 1994), in the presence of serum, have suggested that $T_{3}$ may influence haemopoietic cell differentiation. It remains to be determined whether such $\mathrm{T}_{3}$ effects were absent from our experiments because of a lack of possible co-operating serum components such as cytokines or growth factors (Mooij et al. 1994). Our studies, however, establish that hormone-induced lineagespecific differentiation of HL60 cells is associated with discrete alterations in the stoichiometry of VDR, RXR, $\mathrm{RAR}$ and $\mathrm{T}_{3} \mathrm{R}$ proteins.

We next tested whether these changes correlated with differences in DNA-binding activities of nuclear extracts prepared from monocyte- and neutrophil-differentiated cells. Unique and specific protein-DNA interactions between monocyte or neutrophil extracts and VDRE, RARE or RXRE sequences were demonstrated, indicating that each hormone response element could discriminate between immature, differentiated monocytic and granulocytic HL60 cells. We used anti-receptor antibodies to characterise receptors present in each protein/DNA complex and showed that complexes formed with monocyte extracts were only disrupted by VDR and RXR antibodies whilst those formed with neutrophil extracts were only inhibited by RAR or RXR antibodies. Despite this specificity, antibody disruption of protein/DNA binding was partial, probably resulting from one of two possibilities. First, those complexes that were incompletely disrupted may contain additional unidentified proteins which contribute to the interaction of VDR or retinoid receptors with DNA. Such proteins may include the recently described co-repressor or co-activator proteins that influence nuclear receptor activity (Cavailles et al. 1995, Chen \& Evans 1995, Horlein et al. 1995, Lee et al. 1995). Alternatively, complexes not disrupted by antibodies may contain receptors bound to DNA in configurations that prevent the binding of antibody to its receptor epitope. Although these issues cannot be tested by the methods employed in these studies, the gel shift data demonstrate that monocyte nuclear proteins contain read- ily detectable VDR and RXR, but that RAR and RXR are present in neutrophils. These findings agree well with the Western blotting data and with previous observations on the specificity of $\mathrm{D}_{3}$ and retinoid signalling in HL60 cells (Collins et al. 1977, Breitman et al. 1980, Brown et al. 1994, Bunce et al. 1995).

The studies show that $\mathrm{D}_{3}$-induced monocyte differentiation of HL60 cells correlates with decreased expression of RAR whilst retinoid-induced neutrophil differentiation correlates with reduced expression of VDR. Since RXR is a common heterodimer partner, this indicates that the concentration of RXR is likely to be limiting in this system. Thus, in monocyte-differentiated cells, reduced expression of 'competing' RAR may facilitate VDR/ RXR heterodimer formation whilst, in neutrophildifferentiated cells, the opposite stoichiometric changes may favour RAR/RXR heterodimerisation. This model predicts that hormone-induced monocyte differentiation may be related to decreased expression of the receptor that mediates neutrophil differentiation and vice versa. Indeed, time course studies of RAR $\alpha$ and VDR expression during induction of monocyte differentiation revealed that RAR $\alpha$ expression was reduced and negatively correlated with the onset of differentiation whilst VDR expression was unchanged. Although supportive of the above model, it is important to note, however, that no causal relationship has been demonstrated. Indeed, it is possible that decreased expression of RAR (monocyte differentiation) or VDR (neutrophil differentiation) merely occurs as a consequence of cell differentiation. In this case induction of differentiation would depend on the ligand and would not necessarily require down-regulation of 'competing' receptor. Thus the gradual decline in RAR $\alpha$ expression seen during the induction of monocyte differentiation may only represent the fewer mature monocytes present in cultures treated with $\mathrm{D}_{3}$ for suboptimal time periods. To address these issues in future studies, it will be necessary to determine the temporal relationship between changes in receptor expression and differentiation in individual cells. It will also be important to establish whether such changes in receptor stoichiometry are sufficient to induce altered patterns of expression of the unknown target genes that promote HL60 cell differentiation.

\section{Acknowledgements}

We are grateful to Ms Jennifer Durham and Drs Christopher Bunce and Geoffrey Brown (Department of Immunology, University of Birmingham) for HL60 cells and advice on culture requirements and phenotype assessments. We also thank Dr Lise Binderup (Leo Pharmaceutical Products Ltd, Ballerup, Denmark) for generous supplies of $1 \alpha, 25(\mathrm{OH})_{2}$-vitamin $\mathrm{D}_{3}$ and analogues and Professor Pierre Chambon (Strasbourg, France) for kindly providing RXR antibodies. These studies were funded 
by the Medical Research Council. P GM is in receipt of a University of Birmingham PhD Studentship and G R W a Medical Research Council Clinician Scientist Fellowship.

\section{References}

Ali M, Torian BE \& Vedeckis WV 1992 Identification of human, mouse, and rat retinoic acid receptor alpha using monoclonal antibodies. Biochemical and Biophysical Research Communications 182 1032-1039.

Ballerini P, Lenoble M, Balitrand N, Schaison G, Najean Y \& Chomienne C 1991 Stimulatory effect of thyroid hormone on RA-induced granulocytic differentiation in leukemic cells. Lenkemia 5 383-385.

Binderup L, Latini S, Binderup E, Bretting C, Calverley M \& Hansen K 1991 20-epi-vitamin D3 analogues: a novel class of potent regulators of cell growth and immune responses. Biochemical Pharmacology 42 1569-1575.

Breitman TR, Selonick SE \& Collins SJ 1980 Induction of differentiation of the human promyelocytic leukemia cell line (HL-60) by retinoic acid. Proceedings of the National Academy of Sciences of the USA 77 2936-2940.

Brent GA, Williams GR, Harney JW, Forman BM, Samuels HH, Moore DD \& Larsen PR 1992 Capacity for cooperative binding of thyroid hormone (T3) receptor dimers defines wild type T3 response elements. Molecular Endocrinology 6 502-514.

Brown G, Bunce CM, Rowlands DC \& Williams GR 1994 All-trans retinoic acid and $1 \alpha, 25$-dihydroxyvitamin $\mathrm{D}_{3}$ co-operate to promote differentiation of the human promyeloid leukemia cell line HL60 to monocytes. Leukemia 8 806-815.

Bunce CM, Wallington LA, Harrison P, Williams GR \& Brown G 1995 Treatment of HL60 cells with various combinations of retinoids and $1 \alpha, 25$-dihydroxyvitamin $\mathrm{D}_{3}$ results in differentiation towards neutrophils or monocytes or a failure to differentiate and apoptosis. Leukemia 9 410-418.

Cavailles V, Dauvois S, L'Horset F, Lopez G, Hoare S, Kushner PJ \& Parker MG 1995 Nuclear factor RIP140 modulates transcriptional activation by the estrogen receptor. EMBO Journal 14 3741-3751.

Chen JD \& Evans RM 1995 A transcriptional co-repressor that interacts with nuclear hormone receptors. Nature 377 454-457.

Cheskis B \& Freedman LP 1994 Ligand modulates the conversion of DNA-bound vitamin $\mathrm{D}_{3}$ receptor (VDR) homodimers into VDR-retinoid X receptor heterodimers. Molecular and Cellular Biology 14 3329-3338.

Collins SJ, Gallo RC \& Gallagher RE 1977 Continuous growth and differentiation of human myeloid leukaemic cells in suspension culture. Nature 270 347-349.

Cunningham JM, Purucker ME, Jane SM, Safer B, Vanin EF, Ney PA, Lowrey CH \& Nienhuis AW 1994 The regulatory element 3' to the A gamma-globin gene binds to the nuclear matrix and interacts with special A-T-rich binding protein 1 (SATB1), an SAR/MAR-associating region DNA binding protein. Blood $\mathbf{8 4}$ 1298-1308.

Evans RM 1988 The steroid and thyroid hormone receptor superfamily. Science 240 889-895.

Falcone M, Miyamoto T, Fierro Renoy F, Macchia E \& DeGroot LJ 1992 Antipeptide polyclonal antibodies specifically recognize each human thyroid hormone receptor isoform. Endocrinology 131 2419-2429.

Glass CK 1994 Differential recognition of target genes by nuclear receptor monomers, dimers, and heterodimers. Endocrine Reviews $\mathbf{1 5}$ 391-407.

Glass CK, Lipkin SM, Devary OV \& Rosenfeld MG 1989 Positive and negative regulation of gene transcription by a retinoic acid-thyroid hormone receptor heterodimer. Cell 59 697-708.
Horlein AJ, Naar AM, Heinzel T, Torchia J, Gloss B, Kurokawa R, Ryan A, Kamei Y, Soderstrom M, Glass CK \& Rosenfeld MG 1995 Ligand-independent repression by the thyroid hormone receptor mediated by a nuclear receptor co-repressor. Nature 377 397-404.

Katz RW, Subauste JS \& Koenig RJ 1995 The interplay of half-site sequence and spacing on the activity of direct repeat thyroid hormone response elements. Journal of Biological Chemistry 270 $5238-5242$.

Katzenellenbogen JA, O’Malley BW \& Katzenellenbogen BS 1996 Tripartite steroid hormone receptor pharmacology: interaction with multiple effector sites as a basis for the cell- and promoter-specific action of these hormones. Molecular Endocrinology 10 119-131.

Kliewer SA, Umesono K, Mangelsdorf DJ \& Evans RM 1992 Retinoid X receptor interacts with nuclear receptors in retinoic acid, thyroid hormone and vitamin $\mathrm{D}_{3}$ signalling. Nature 355 446-449.

Lee JW, Ryan F, Swaffield JC, Johnston SA \& Moore DD 1995 Interaction of thyroid-hormone receptor with a conserved transcriptional mediator. Nature 374 91-94.

Leid M, Kastner P, Lyons R, Nakshatri H, Saunders M, Zacharewski T, Chen JY, Staub A, Garnier JM, Mader S \& Chambon P 1992 Purification, cloning, and RXR identity of the HeLa cell factor with which RAR or TR heterodimerizes to bind target sequences efficiently. Cell 68 377-395.

Macchia E, Nakai A, Janiga A, Sakurai A, Fisfalen ME, Gardner P, Soltani K \& DeGroot LJ 1990 Characterization of site-specific polyclonal antibodies to c-erbA peptides recognizing human thyroid hormone receptors $\alpha 1, \alpha 2$, and $\beta$ and native $3,5,3^{\prime}$-triiodothyronine receptor, and study of tissue distribution of the antigen. Endocrinology 126 3232-3239.

Mangelsdorf DJ 1994 Vitamin A receptors. Nutritional Reviews 52 S32-S44.

Mangelsdorf DJ, Borgmeyer U, Heyman RA, Zhou JY, Ong ES, Oro AE, Kakizuka A \& Evans RM 1992 Characterization of three RXR genes that mediate the action of 9-cis retinoic acid. Genes and Development 6 329-344.

Mattei MG, Riviere M, Krust A, Ingvarsson S, Vennstrom B, Islam MQ, Levan G, Kautner P, Zelent A \& Chambon P 1991 Chromosomal assignment of retinoic acid receptor (RAR) genes in the human, mouse, and rat genomes. Genomics 10 1061-1069.

Mooij P, Simons PJ, de Haan-Meulman M, de Wit HJ \& Drexhage HA 1994 Effect of thyroid hormones and other iodinated compounds on the transition of monocytes into veiled/dendritic cells: role of granulocyte-monocyte colony-stimulating factor, tumour-necrosis factor-alpha and interleukin 6. Journal of Endocrinology 140 503-512.

Ozono K, Sone T \& Pike JW 1991 The genomic mechanism of action of 1,25-dihydroxyvitamin $\mathrm{D}_{3}$. Journal of Bone and Mineral Research 6 1021-1027.

Pike JW, Donaldson CA, Marion SL \& Haussler MR 1982 Development of hybridomas secreting monoclonal antibodies to the chicken intestinal $1 \alpha, 25$-dihydroxyvitamin $\mathrm{D}_{3}$ receptor. Proceedings of the National Acadamy of Sciences of the USA 79 7719-7723.

Rochette Egly C, Lutz Y, Pfister V, Heyberger S, Scheuer I, Chambon P \& Gaub MP 1994 Detection of retinoid X receptors using specific monoclonal and polyclonal antibodies. Biochemical and Biophysical Research Communications 204 525-536.

Rosen ED, Beninghof EG \& Koenig RJ 1993 Dimerization interfaces of thyroid hormone, retinoic acid, vitamin $\mathrm{D}$, and retinoid $\mathrm{X}$ receptors. Journal of Biological Chemistry 268 11534-11541.

Schrader M, Muller KM, Nayeri S, Kahlen JP \& Carlberg C 1994 Vitamin $D_{3}$-thyroid hormone receptor heterodimer polarity directs ligand sensitivity of transactivation. Nature 370 382-386.

Titcomb MW, Gottardis MM, Pike JW \& Allegretto EA 1994 Sensitive and specific detection of retinoid receptor subtype proteins in cultured cell and tumor extracts. Molecular Endocrinology 8 870-877. 
Toksoz D, Bunce CM, Stone PC, Michell RH \& Brown G 1982 Variant cell lines from the human promyelocyte line HL60. Leukaemia Research 6 491-498.

Umesono K, Murakami KK, Thompson CC \& Evans RM 1991 Direct repeats as selective response elements for the thyroid hormone, retinoic acid, and vitamin $\mathrm{D}_{3}$ receptors. Cell 65 1255-1266.

Williams GR 1994 Hormones. Solving the specificity puzzle. Nature 370, 330-331.

Williams GR, Harney JW, Forman BM, Samuels HH \& Brent GA 1991 Oligomeric binding of $\mathrm{T}_{3}$ receptor is required for maximal $\mathrm{T}_{3}$ response. Journal of Biological Chemistry 266 19636-19644.

Williams GR, Bland R \& Sheppard MC 1994 Characterization of thyroid hormone $\left(\mathrm{T}_{3}\right)$ receptors in three osteosarcoma cell lines of distinct osteoblast phenotype: interactions among $\mathrm{T}_{3}$, vitamin $\mathrm{D}_{3}$, and retinoid signaling. Endocrinology 135 2375-2385.

Williams GR, Bland R \& Sheppard MC 1995 Retinoids modify regulation of endogenous gene expression by vitamin $\mathrm{D}_{3}$ and thyroid hormone in three osteosarcoma cell lines. Endocrinology 136, 4304-4314.
Yam LT, Li CY \& Crosby WH 1971 Cytochemical identification of monocytes and granulocytes. American Journal of Clinical Pathology 55 283-290.

Yen PM, Darling DS, Carter RL, Forgione M, Umeda PK \& Chin WW 1992 Triiodothyronine $\left(\mathrm{T}_{3}\right)$ decreases binding to DNA by $\mathrm{T}_{3}$-receptor homodimers but not receptor-auxiliary protein heterodimers. Journal of Biological Chemistry 267 3565-3568.

Zechel C, Shen XQ, Chambon P \& Gronemeyer H 1994 Dimerization interfaces formed between the DNA binding domains determine the cooperative binding of RXR/RAR and RXR/TR heterodimers to DR5 and DR 4 elements. EMBO Journal 13 1414-1424.

Zhang XK, Lehmann J, Hoffmann B, Dawson MI, Cameron J, Graupner G, Hermann T, Tran P \& Pfahl M 1992 Homodimer formation of retinoid $\mathrm{X}$ receptor induced by 9 -cis retinoic acid. Nature 358 587-591.

Received 24 March 1997

Revised manuscript received 1 July 1997

Accepted 26 August 1997 